\title{
An Analysis on Social Security in Brazil Based on Maranhão
}

\author{
Fernando Silva Lima ${ }^{1}$, Alessandra Silva Pires ${ }^{1}$, Francisco de Assis Pereira Filho ${ }^{1} \&$ Michelle Matilde Semiguem \\ Lima Trombini Duarte ${ }^{2}$ \\ ${ }^{1}$ Federal Institute of Education, Science and Technology of Maranhão (IFMA) - Carolina Advanced Campus, \\ Maranhão State, Brazil \\ ${ }^{2}$ Regional Development, the Federal University of Tocantins (UFT) \\ Correspondence: Fernando Silva Lima, Professor, Federal Institute of Education, Carolina Advanced Campus, \\ Science and Technology of Maranhão (IFMA) - Carolina Advanced Campus, Rua Imperatriz, City of Carolina, \\ Maranhão State, Brazil. \\ Received: November 23, 2019 \\ Accepted: January 10, 2020 \\ Online Published: January 18, 2020 \\ doi:10.5430/ijba.v11n1p1 \\ URL: https://doi.org/10.5430/ijba.v11n1p1
}

\begin{abstract}
This study begins with the question: can the new change in the old-age pension system improve the economic-financial performance of the National Institute of Social Security in Brazil? The hypothesis is that the proposed constitutional amendment (PEC) 287/16, which is being presented at the Chamber of Deputies known as the pension reform, including an attempt to change the minimum age for men and women, will not solve the problem of economic crisis and financial expenses of the National Institute of Social Security of Brazil, due to the fact that the greatest impact may be other expenses not identified in this study that revolve around the benefits of retirement. The general objective is to analyze the economic and financial situation of social security in Brazil based on the regional accounting records located in Imperatriz and São Luís do Maranhão between 2008 and 2017. The methodology was defined as descriptive, explanatory and average, such as bibliofigurey, documentary and field. One of the results regarding the increase in the retirement age shows that there is no relation between the income increase indicators when compared to the surplus (profit) or deficit (loss) between 2008 and 2017 in the Social Security of Maranhão.
\end{abstract}

Keywords: social security, social policies, retirement, Maranhão

\section{Introduction}

The problem of this study was based on a conception that the public power has already made several changes in the social security legislation, especially with regard to pensions, however, it was noticed that part of these changes occurred in the period in which "the behavior of the collection of the INSS (Initials in Portuguese for National Institute of Social Security) from the contributions of employees and employers and the value of the expenses with the payment of social security benefits, [...] shows that until 1992 the value of contributions exceeded the benefits."

Incidentally, it is evident that the 1998 change was pointless, attribufigure to the fact that the main reason for the reform was the increase in the average age of concession of the benefit, implying extension of the contribution period, reduction of expenses in the short term due to the delay of the concession and reduction of the expenses of long term for the concession for a shorter period (CECHIN, 2002).

In a survey led by Marques and Batich between 1997 and 1998, the collection of contributions from employees and employers was increasingly insufficient to finance increasing spending on benefits.

According to the authors, "between January 1991 and December 1998, the participation of the salaried worker without a formal contract in the total employed population increased by 5 percentage points" and that "the total open unemployment rate in Brazil, calculated by IBGE, increased from 3.4\% to 7.6\% between 1989 and 1998 (MARQUES e BATICH, 1999, pp. 149, 152).

Although the reform advocated by public authorities and investors claiming that the changes imposed are necessary for recovering the accumulated losses in social security, and for this, there should be a new adjustment in the minimum age to retire, consequently, it has, somehow, divided the public opinion.

In a study presented by Silva and Costa (2016), it was revealed that only in 2015, the federal government transferred more than $47 \%$ (forty-seven percent) of its budget to the financial system, which represented an expense of about 1.3 
trillion BRL to something around 2.6 (two point six) times greater than the expenses with the payment of all social security benefits.

For Marques and Batich (1999), the arguments used in the defense of radical reform remain the same as ever, specifically, those who advocate it are tireless in pointing out that the fragility of Social Security financing stems from the fact that the granting of benefits is not based on solid actuarial bases - among other aspects, do not take into account the aging process of the population - and it constitutes a source of several of the inequities that persist in the current system.

Therefore, the following question has arisen: Can the new change in the old-age pension system improve the economic and financial performance of the National Institute of Social Security in Brazil?

The hypothesis is that the proposed constitutional amendment (PEC) $287 / 16$, which is being presented at the Chamber of Deputies known as the pension reform, together with a try to change the minimum age for men and women, will not solve the problem of economic crisis and financial expenses of the National Institute of Social Security of Brazil, for the reason that the greatest impact may be other expenses not identified in this study that revolve around the benefits of retirement.

As a result, taking into account the economic and financial situation of Brazil, this study is justified because it will contribute to public policies, however, taking into account the social differences in each region, based in Maranhão.

Maranhão is one of the poorest federal units in the Northeast and of the country, as it has great needs and few social indicators that influence the economic and income structure, and this has aggravated the deficit of public services (CARVALHO, 2015).

This study is also relevant because it analyzes the condition of granting social security benefits related to age, income, and contribution, urban or rural activity in which it affects the life of the Brazilian citizen.

In view of this, it is understood that the changes in the social security system that may arise if the proposed constitutional amendment (PEC) $287 / 16$, called social security reform is approved at the national congress, may have impacts that will affect citizens in all Brazilian states.

These consequences may seem detrimental to the poor, as any change in the social security system requires attention to the particular development of each region, otherwise poverty and misery may increase because, in general, these changes may make it difficult to access benefits, which so far has been one of the ways to reduce regional inequality in Brazil.

It is worth mentioning that this study is of great importance both for researchers and for society in general, which can corroborate evidencing the financial situation of the social security system.

Consequently, the overall objective of this study is to analyze the economic and financial situation of social security in Brazil based on the accounting balance sheets of the regional offices located in Imperatriz and São Luís do Maranhão between 2008 and 2017.

The specific objectives are to identify the average number of contributors receiving social benefits in Maranhão; identify specifically the retirement that most generates impact on the resources derived from social benefits; compare the amounts spent on retirement by age with the surplus (profit) or deficit (loss) of the National Institute of Social Security in the State; analyze the cash balance in relation to the surplus (profit) or Deficit (loss) in the National Institute of Social Security in Maranhão.

\section{Theoretical Aspects}

\subsection{Social Security, Maranhão and Brazil's Economic Crisis}

In Brazil, the idea of social security emerged at the end of the 20th century, where employees of a company, without the direct participation of public power, felt the need to create aid funds to guarantee subsistence when they could not work (BATICH, 2004).

According to Brazilian law, Social Security comprises an integrated set of initiatives by the public authorities and society, designed to ensure the rights related to health, social security and social assistance (BRASIL, CF, 1988).

On the word of Friedman (1984) up to the 1930s, the entrepreneur would bear all the cost of reproduction of the worker in the final composition of the product or service rendered. This system worked and was inherited from the slave period, where the entrepreneur had all costs of reproduction built into productive training, i.e., it was the responsibility of the company to create and maintain, besides salary, the institution and maintenance of so-called villages (housing, education, health, welfare and assistance, among other costs). 
As stated by Furtado (1980, p.81), "from the Revolution of 30, when the industrialization project was established, which was already late compared to the stages of original industrialization", which occurred at the apex of world capitalism, most of costs of reproduction of the workforce was extirpated from the company's internal production structure. Specifically, in addition to covering food and clothing, the salary enjoyed monthly by the urban employee had to participate also with expenses of rent, welfare and assistance, education, health, among others. At that point, the definition of the minimum wage (created in 1940) and state financing of education, health, welfare and welfare public policies (SPOSATI, 1985) became more prominent.

"In reality, a system of social protection of a meritocratic and particularistic nature with corporatist and clientelistic nuances was established" (Draibe, 1985, p. 73), dedicated exclusively to salaried and signed workers. At that time, the majority of the workers were of the rural category, that is to say, only the urban employees were contemplated with the minimum wage, as well as by all the social and labor legislation.

Along with Aureliano (1989, p. 21), "overall, social protection financing accounted for about $1 / 3$ of the total urban employee cost, which made access to the formal contract of employment more difficult." Even with these tensions, in 1923, a law was passed that was a forerunner in terms of the Brazilian social security experience (rail workers' retirement fund), which was changed by law to the main urban professional classes (retirement institutes and pensions) from the 30's. Only in the 60's was the health and welfare and retirement fund for rural workers (Funrural) established just after the unification of retirement and pension funds for urban employees (National Institute of Social Security).

Signs of regression in the social protection system in Brazil are not negligible, given the fall in labor income, the expansion of open unemployment and precarious occupations. On the other hand, the expansion of social security, social assistance and income guarantee (welfare of rural workers, Organic Law on Social Assistance and income transfer programs) helps to combat poverty and social inequality, even though it does not replace the income of work (DRAIBE, 1985, p. 181).

Consistent with the aforementioned, in Brazil, it is necessary to leverage economic growth, unlike developed countries that have practically a static population or with low demofigureic mutation. Brazil has room to optimize and seek the efficiency and effectiveness of social spending, despite a considerable and important part of the population has not yet awakened to the contribution to social financing. In Pochmann's words (2003, p. 91), "it is observed that only one person in three is protected by labor laws, while only one in two contributes to social security and welfare."

In this context, it is understood that social insurance has undergone a series of parametric changes in Brazil and that, at the moment, social security may undergo further changes in the policy of granting benefits, in case of the Proposal for a Constitutional Amendment (PEC) of 2016 be approved in the Chamber of Deputies and in the Federal Senate, because it can, mainly in the ranges of pensions, retirement pensions by death and disability, including in retirement by age.

Differently from what the Brazilian press has shown about PEC 287 of 2016, in which it seeks to demonstrate the need to approve the proposal in order to combat the privileges of a part of the population benefiting from social security.

There is a conception that PEC 287 of 2016 aims to demand a greater sacrifice of Brazilian society with regard to the granting of social benefits, including those living in the poorer states of Brazil, as Maranhão, that has great needs and few social indicators that influence income and economic structure and this has aggravated the deficient supply of public services (CARVALHO, 2015)

In line with the 2010 census, Maranhão continues to figure in the national scenario as one of the federation's units with the worst social indicators, due to a population of 6.5 million, and 1.7 million living below the poverty line or extreme poverty whose income is up to 70 BRL per month, specifically, corresponds to $25.7 \%$ of its inhabitants, more than triple the national average, which is $8.5 \%$. In the absolute poverty line, which corresponds to a monthly per capita family income of up to half a minimum wage, the numbers are even more evident: $55.9 \%$ of the population of Maranhão, more than 3.4 million people, survives in this condition (ARAÚJO e BRANDÃO, 2011).

From this perspective, it can be seen that the possible changes in the social security regime can directly impact individuals residing in the State of Maranhão, since the pension reform begins with the economic crisis that Brazil entered the second quarter of 2014, with a GDP growth of only $0.5 \%$ in that year, worsening in 2015 and 2016, with declines of $-3.8 \%$ and $-3.6 \%$, respectively (IBGE).

It is conceived, that the economic crisis has been aggravated by political questions at the moment that the 
impeachment process against the former president Dilma Rousseff was opened on 2nd of December, 2015, because, from that process there was no resumption of growth in the country nor the way forward for a solution to the fiscal problem. For instance, the structural fiscal deficit of 2016 was close to $2 \%$ of the GDP, which indicates that in order to reach a surplus of $2.5 \%$ (to stabilize the debt), the country would have to make fiscal consolidation of around $4.5 \%$ of GDP.

Accordingly, the alternative of the federal public power would be to make an immediate or gradual consolidation to enable a stabilization of the debt to GDP ratio.

For this reason, the PEC of the spending ceiling was implemented and the pension reform is being articulated in order to stabilize and reduce Brazil's risk independently of the peculiarities of the Brazilian states, including Maranhão.

\subsection{The Social Security Reform in Brazil}

It is noticeable that, due to the economic and financial crisis in Brazil, public social security policies have been one of the main concerns of national and international investors.

In Brazil, for example, issues involving the sustainability of the pension system, coverage, strengthening of financing mechanisms and rules on access to benefits, such as minimum age, contribution time and social security factor, among others, has been the biggest impasse.

It is understood that the social security system in Brazil has noticed that life expectancy increases in all the age groups, including the elderly, and this can have a direct consequence the load of welfare benefits, for that reason, it has been demanded frequent debates on the need to reform the welfare and the adequacy of the social rights guaranteed by the Federal Constitution of Brazil.

It occurs that, on the word of Trindade (2017), official estimates show that the deficit of the National Institute of Social Security should increase substantially in the coming years.

As a result, there has been a concern with the maintenance of income and quality of life, since society is losing confidence in the capacity of Social Security to guarantee the benefits.

Conversely, in keeping with Queiroz (2017), the possible pension reform will mean that Brazil, besides being one of the most unequal and heterogeneous countries in the world, will become one of the world champions in restrictive rules for retirement, and will also have two serious consequences:

- The first is the increase in the number of unprotected workers, in addition to the current 25 million (37.7\% of the total).

- The second is the real financial loss of social security, due to the retraction of the incomes of the poorest sectors, intensified by the migration of the richer classes to the private sector.

Afonso and Zylberstajn (2017) concluded that the original version of the reform, presented by the executive branch at the end of 2016, improves the actuarial justice of the system and aggravates the distributive progress of income, justifying that women are most affected by the loss of five years of retirement, and the lowest income insured, since the retirement by age would have, in this version of the reform, raised from 15 to 25 years.

Subsequently, the elaboration of PEC 287/2016 underwent modifications from December 2016 to December 2017, analyzed by Ferreira (2018), who also used PNAD data and projected insured persons who would be retired after a 30-year horizon considering the current rules compared to two versions of PEC 287/2016.

The author separated the insureds by income, occupation, region, color and schooling, analyzing who would continue to retire and who could no longer retire with the changes, concluding that women and rural would be the biggest losers in the original proposal presented by the government at the end of 2016, whose effect would be reversed for the rural ones by the modification of the legislature in the end of 2017.

\section{Method}

This research is qualitative in nature because of the attributes of the information collected and quantitative due to the numerical data analyzed. The object of study is the National Institute of Social Security (INSS - initials in Portuguese for National Institute of Social Security) of the State of Maranhão.

Initially, this study sought to carry out a theoretical survey on Social Security to support the understanding of the economic and financial situation of the Institution previously mentioned.

At the end of this stage, the researchers sought to collect information through the portal of the federal government's 
information system access system (SIC) between 2008 and 2017, the amounts paid and the amount of social security benefits intended for the taxpayers of Maranhão, in a detailed manner, so that they could figureically analyze the economic and financial situation of the Brazilian Social Security, through the regional unit of Maranhão.

As a consequence, it can be observed that in figures 1 and 2, there are information on which the ANOVA test was applied, but presented according to the Pareto diagram.

It is important to clarify that the Pareto diagram method is different from the test (ANOVA) because, while the Pareto diagram is a tool that serves to separate the few vital problems from the many trivial problems (PEINADO e GRAEML, 2007, p. 546).

Therefore, it is believed that this method is essential for separating, on average, the largest beneficiaries of social security and detailing the types of retirees of the Maranhão region. In contrast, the ANOVA test is a tool to determine the degree of confidence in the form of percentage in relation to the data analyzed according to figures 1 and 2 (PAESE, CATEN e RIBEIRO, 2001).

It is understood that the Pareto principle can be applied to any public and private company and decide what is a priority, what is more representative for the nature of the business, to evaluate what is relevant, to contextualize the failures and to identify the actions that would work in the $20 \%$ effort that provides $80 \%$ of the result (Vazquez \& Dos Santos, 2010).

In the Pareto diagram, the effects of the rectangles exceed the right of the dividing line (0.5) are statistically significant, at the $95 \%$ confidence level in relation to the others. While positive effects are associated with an increase in the response variable, negative effects indicate that an increase in that parameter reduces the response variable considered (ARAÚJO, 2012).

For the analysis of figures 3 and 4, Pearson's coefficient was required, which is a measure of bivariate association (strength) of the degree of relationship between two variables where it measures the direction and degree of linear relationship between two variables and quantitative (MOORE, 2007, pp. 100 and 101).

On the other hand, Pearson's coefficient shows linearly the increase or decrease of one unit in variable $\mathrm{X}$ and the same impact on variable Y. In figureical terms, by linear relation it is understood that the best way to illustrate the pattern of relationship between two variables is through a straight line. Therefore, the Pearson correlation (r) requires a sharing of variance and that this variation is linearly distributed (FIGUEIREDO FILHO e SILVA JÚNIOR, 2009).

The Pearson correlation coefficient (r) varies from -1 to 1 . In the Person correlation coefficient, the values can indicate positive or negative direction of the relationship and even show strength of the relationship between variables, so a correlation to make perfect (-1 or 1) must necessarily be exact, but also, if the value of a correlation is zero indicates that there is no linear relationship between the variables (FIGUEIREDO FILHO e SILVA JÚNIOR, 2009).

However, extreme values ( 0 or 1$)$ are difficult to find in practice, it is important to discuss how researchers can interpret the magnitude of coefficients (FIGUEIREDO FILHO e SILVA JÚNIOR, 2009).

Therefore, Cohen (1988) says that values between 0.10 and 0.29 can be considered small; scores between 0.30 and 0.49 can be considered the mean; and values between 0.50 and 1 can be interpreted as large and for Dancey and Reidy (2006) they point to a slightly different classification: $r=0.10$ up to 0.30 (weak); $r=0.40$ to 0.6 (moderate); $r$ $=0.70$ to 1 (strong).

\section{Results}

In this study, significant differences were found between social security benefits (ANOVA; F4.49=346.7130813; P = 0.00 which means $\mathrm{P}<0.01$ or $1 \%$ ); therefore, it is considered that this test indicates a confidence of $99 \%$ in relation to the data presented in the present study (Figure 1). 


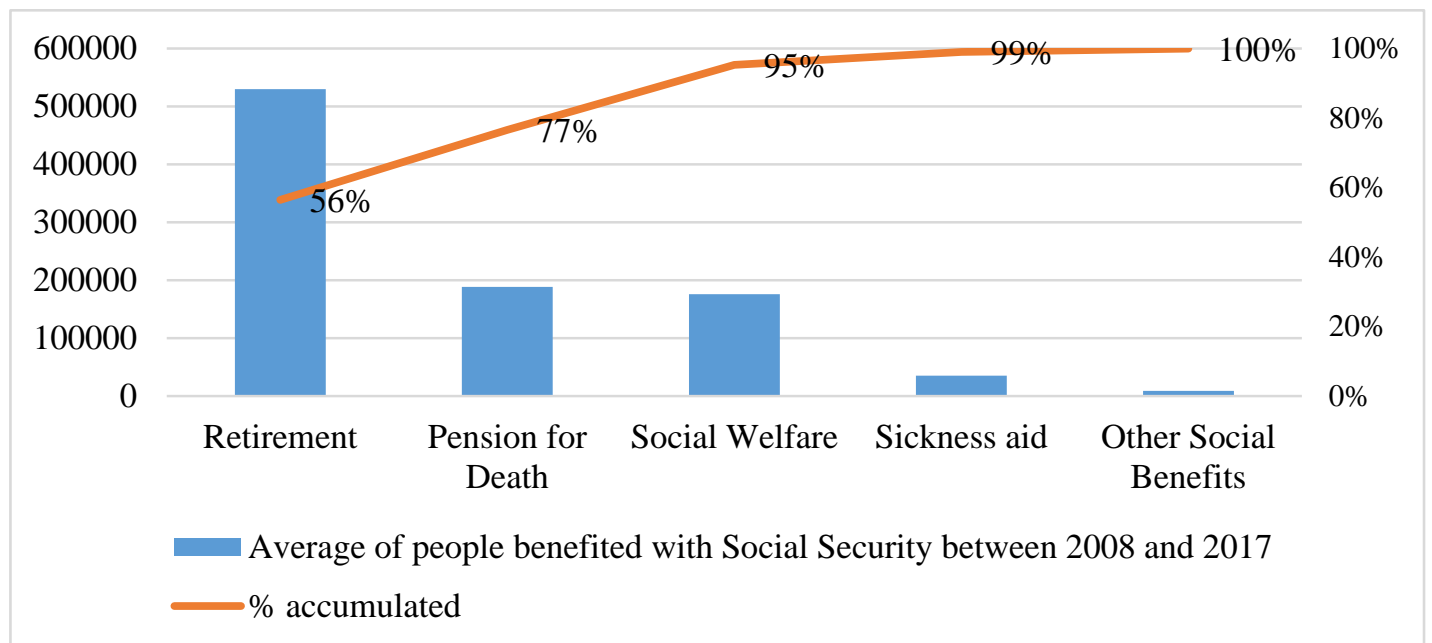

Figure 1. Average number of social security beneficiaries in the state of Maranhão between 2008 and 2017 Source: prepared by the authors

In Maranhão, for example, as shown in Figure 1, it can be observed that most taxpayers who received social security benefits between 2008 and 2017, almost $60 \%$ of beneficiaries, come from pensions.

Based on the Pareto diagram (Figure 1), it can be said that public authorities should carefully examine all changes in the pension system, especially when it comes to the availability of financial resources to pay for these benefits.

The fact is that, according to the National Association of Brazilian Internal Revenue Auditors - ANFIP, (2018), the first Constitutional Amendment No. 93/2016, promulgated in September, extended and expanded the decoupling of federal revenues, effective until 2023, subtracting from Social Security 30\% of revenue social contribution, except social security social security fees and inspection. Previously, the untying was $20 \%$, which did not touch the rates. A device has granted the extension retroactively and its effects have been extended to January 2016.

The second, Constitutional Amendment No. 95/2016, created the New Fiscal Regime, lasting 20 years. Thus, one-year expenses were limited to the amount executed in the previous year plus inflationary correction.

These provisions are already valid for 2017. Of course, these limitations apply only to so-called primary expenditures, practically the budget spent on society, expenditures on benefits, education, justice, security, miscellaneous investments. For interest expense and other debt charges, there are no restrictions. This measure directly or indirectly changes the provisions on minimum health, education and social spending (ANFIP, 2018).

For that reason, it is understood that any change in retirement rules may result in greater consequences for Brazilian society. Regarding retirement benefits, Figure 02 sought to identify the type of retirement that generated the highest social security cost in Maranhão between 2008 and 2017.

It must also be highlighted that in Figure 2 significant differences were found between social security benefits (ANOVA; F20.189 $=56.18389443 ; \mathrm{P}=0.00$, which means $\mathrm{P}<0.1$ or $1 \%$ ), consequently, it is considered that this test indicates a confidence of $99 \%$ in relation to the data presented. 


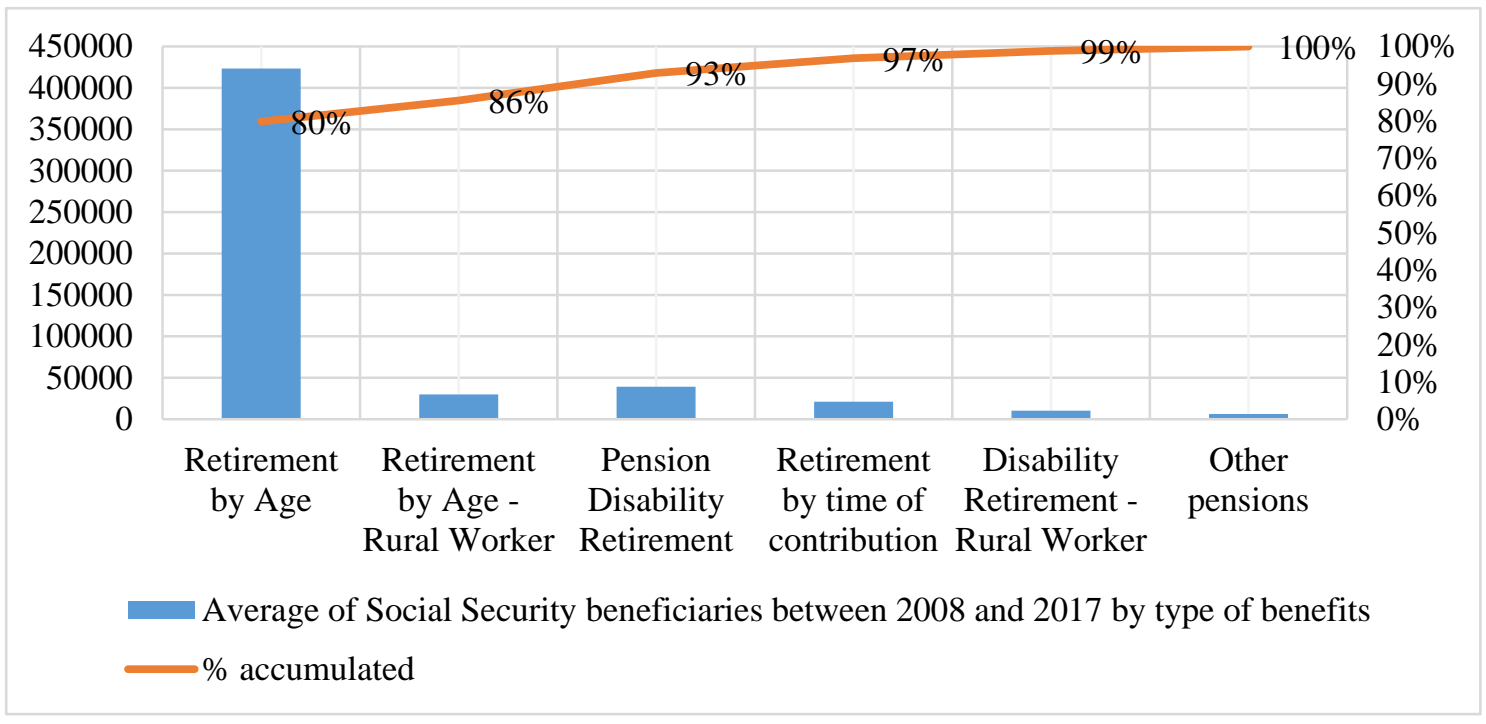

Figure 2. Average number of retired taxpayers by specificity in Maranhão between 2008 and 2017

Source: prepared by the authors

In Figure 2, retirement by age represents the highest cost compared to other benefits, however, according to ANFIP (2018) in 2016, expenses with the title of "other government areas" increased by 4.5 billion BRL, which corresponds to the administrative expenses that in the reports showed and which were earmarked for social security where, for the organization, this effect derives directly from the union of federal ministries.

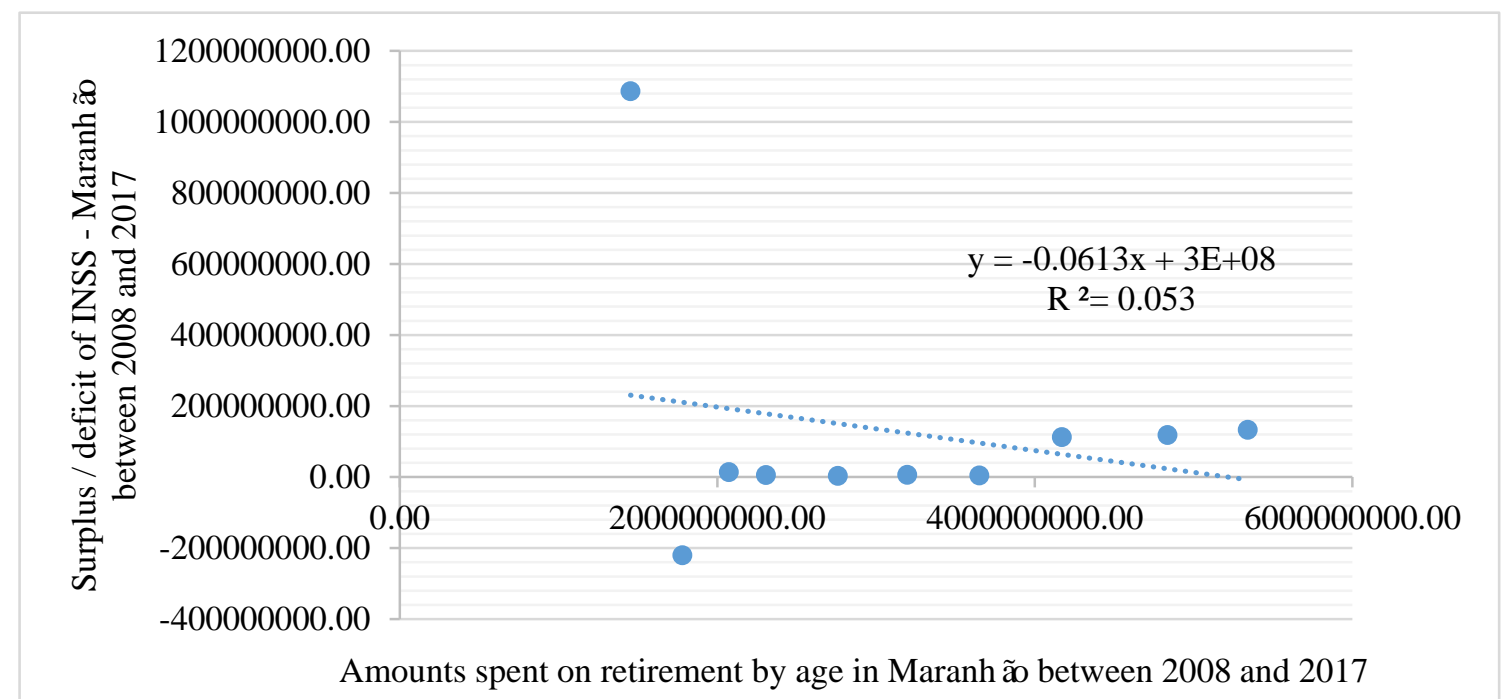

Figure 3. Analysis of the ratio of the amounts spent on pensions by age with the Surplus (profit) or Deficit (loss) in Maranhão between 2008 and 2017

Source: prepared by the authors

As it can be seen in Figure 3, the values spent on pension by age compared to the surplus or deficit of the National Institute of Social Security (INSS) of Maranhão in the analyzed period show low linear correction when tested, therefore, according to the variables, there is a weak negative relationship, since $\mathrm{R}=0.24$ and $\mathrm{R} 2=0.05$ in this period. 
Based on the surplus and deficit in INSS of Maranhão, it is believed that the hypothesis that a reform is needed to improve the surplus and the social security deficit in Brazil is unsustainable, as it shows that only $24 \%$ of surplus and deficit problems are linked to the payment of this benefit.

ANIFIP (2018) has pointed out that for the refinancing of social security debts of states and municipalities, in the amount of 90 billion BRL, the federal government issued the Provisional Measure No. 778/2017, converted into Law No. 13,485 / 201748 which forgives almost 40 billion BRL when it is considered that the reductions of interest and fines and the installment that will reach almost 25 years.

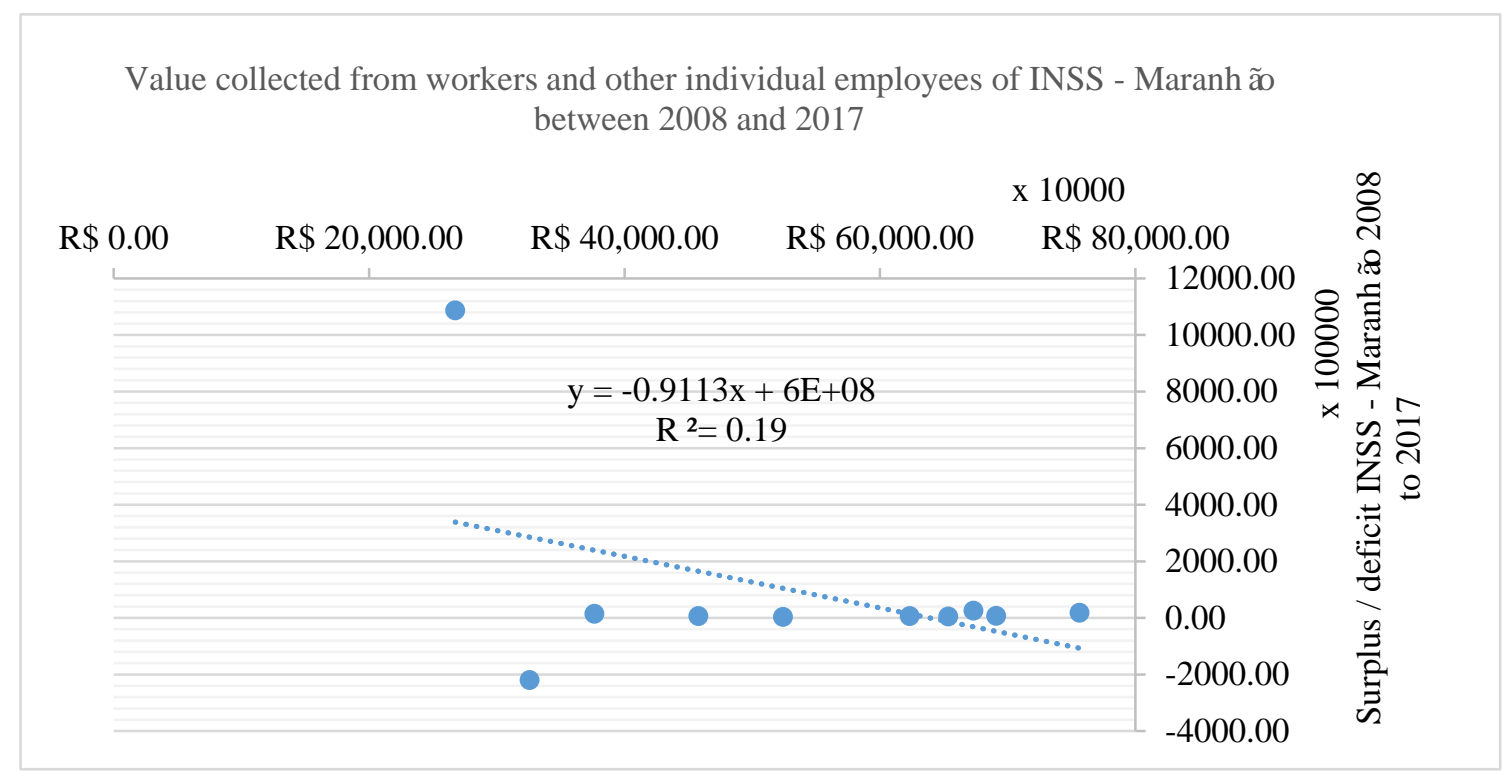

Figure 4. Analysis of the Value collected from workers and other individual employees of INSS - Maranhão between 2008 and 2017

Source: prepared by the authors

Another determining factor is presented in Figure 4, which shows the comparison between the amount that workers are charged in Maranhão and the surplus and deficit of the National Institute of Social Security of this region between 2008 and 2017, because the variables tested revealed a weak negative relationship where $\mathrm{R}=-0.43$ and R2 $=0.19$.

Figures 3 and 4 reveal that the variables analyzed in relation to social income and minimum retirement age, when compared to the surplus and the institutional deficit, have a low impact on the public finance balance of the National Institute of Social Security of Maranhão. In this case, the other impacts of the financial system of social security may be related to deviations from social security resources to pay interest on public debt, in addition to the problem of lack of transparency in social security data (GENTIL, 2006, 2017).

Accordingly, PEC 247/2016, which has been the main proposal of the Brazilian government to reform the Brazilian social security system, has not been a convincing argument for Brazilians, since the minimum retirement age is only one of the intrinsic factors that generated scarcity of public resources.

Nonetheless, if the Brazilian government seeks to better manage social security resources, there may be a better guarantee for future individuals who need to retire, which will surely solve the problems that make retirement and other services offered to society an issue. It is noteworthy that the expenses that revolve around retirement by age should be prioritized, since these costs, according to Pareto's diagram, highlight one of the main sectors that suffer from the financial crisis of the National Institute of Social Security.

Instead of rulers seeking to reduce access to the social insurance system, it is suggested that they propose a cost-cutting alternative to meet the number of beneficiaries. For instance, instead of increasing retirement time, it is 
recommended that the government develop policies to bring older people into the job market and encourage older people to retire later.

Finally, it is suggested that the federal government take the necessary measures and reassess the policies implemented to verify the effectiveness of actions in the social security system in Brazil.

\section{Conclusion}

Considering that the general objective of this study was to analyze the economic and financial situation of social security in Brazil based on the National Institute of Social Security of Maranhão between 2008 and 2017 this study concludes with the experience that the social security system in Brazil is each diluted as access to welfare services becomes more difficult.

This experience gives the impression that there was a misunderstanding on the part of society regarding the proposed constitutional amendment (PEC), in which, in Congress, the social actors had to convince society by aligning the discourse that social security reform was necessary due to the economic and financial situation of the institution.

Thus, it is concluded that the hypothesis that social security reform, even seeking to change the minimum age for men and women, will not solve the problem of the economic and financial crisis of the National Institute of Social Security, because the problem with the greatest impact is the expenses. that revolve around social security benefits are confirmed..

\section{References}

Afonso, L. E., \& Zylberstajn, H. (2017). Uma avaliação dos impactos distributivos da Proposta de Emenda Constitucional 287/2016 sobre os benefícios programáveis de aposentadoria do RGPS. USP International Conference in Accounting, 17, 1-20.

ANFIP - Associação Nacional dos Auditores-Fiscais da Receita Federal do Brasil., \& Fundação ANFIP de Estudos da Seguridade Social. (2018). Análise da Seguridade Social 2017/ANFIP/Fundação ANFIP de Estudos da Seguridade Social. Brasília: ANFIP. Retrieved September 11, 2019, from https://www.anfip.org.br/wp-content/uploads/2018/12/Livros_28_11_2018_14_51_18.pdf

Araújo, C. C., \& Brandão, S. M. S. de O. (2011). A pobreza no Maranhão: determinantes ideo-políticos. V Jornada Internacional de Políticas Públicas. Retrieved September 7, 2018, from http://www.joinpp.ufma.br/jornadas/joinpp2011/CdVjornada/JORNADA_EIXO_2011/MESAS_TEMATICAS/ A_QUESTAO_DA_POBREZA_NO_MARANHAO_DETERMINANTES_E_NEW.pdf

Araújo, J. S. (2012). Estudo Paramétrico do Processo de Combustão in situ como Método de Recuperação Avançada de Petróleo. Janusa Soares de Araújo. Retrieved December 18, 2018, from http://www.nupeg.ufrn.br/documentos_finais/teses_de_doutorado/teses/janusaaraujo.pdf

Aureliano, L. (1989). A especificidade do Welfare State brasileiro. MPAS/CEPAL (Org.), A política social em tempo de crise: articulação e descentralização. Brasília: MPAS.

Batich, M. (2004). Previdência do trabalhador: uma trajetória inesperada. São Paulo em Perspectiva, 18(3), 33-40. Retrieved October 24, 2018, from http://www.scielo.br/pdf/spp/v18n3/24776.pdf

Brasil, Constituição Federal do Brasil - CF. (1988).

Carvalho, F. C de. (2015). Política de desenvolvimento regional-territorial e governança: Uma análise recente sobre o Estado do Maranhão (Brasil). Ph.D Dissertation, St. Paul State University. Retrieved November 23, 2018, from https://repositorio.unesp.br/bitstream/handle/11449/138539/000864210.pdf?sequence=1

Cechin, J. (2002). A previdência social reavaliada II. Conjuntura Social, Brasília, DF, MPAS.

Cíntia, P., Tem, C. C., \& José Luis Duarte, R. (2001). Aplicação da Análise de Variância na Implantação do CEP. Artigo. Revista Produção, 11(1). Retrieved September 4, 2019, from http://www.scielo.br/pdf/prod/v11n1/v11n1a02.pdf

Cohen, J. (1988). Statistical power analysis for the behavioral sciences. Hillsdale, NJ, Erlbaum.

Dancey, C., \& Reidy, J. (2006). Estatística Sem Matemática para Psicologia, Usando SPSS para Windows. Porto Alegre, Artmed.

Draibe, S. (1985). Rumos e metamorfoses. Rio de Janeiro: Paz e Terra.

Ferreira, M. M. (2018). Simulação dos impactos da reforma da previdência sob a ótica da renda. São Paulo. 
Retrieved November 15, 2018, from https://bibliotecadigital.fgv.br/dspace/handle/10438/20413

Figueiredo Filho, D. B., \& Silva Júnior, J. A Da. (2009). Desvendando os ministérios do coeficiente de correlação de

Pearson (r). Política Hoje, 18(1). Retrieved May 30, 2017, from https://www.google.com.br/url?sa=t\&rct=j\&q=\&esrc=s\&source=web\&cd=1\&ved=0ahUKEwjDz87U55_JAhX MrpAKHRVaBY8QFgggMAA\&url=http\%3A\%2F\%2Fwww.revista.ufpe.br\%2Fpoliticahoje\%2Findex.php \%2F politica\%2Farticle\%2FviewFile\%2F6\%2F6\&usg=AFQjCNG1QfVVdplHcuhmm8rYnQMWpVxlvA

Friedman, M. (1984). Capitalismo e liberdade. São Paulo: A. Cultural.

Furtado, C. (1980). O mito do desenvolvimento econômico. São Paulo: Paz e Terra.

Gentil, D. L. (2006). A Política Fiscal e a Falsa Crise da Seguridade Social Brasileira - Análise financeira do período 1990-2005. Ph.D Dissertation, Universidade Federal do Rio de Janeiro.

Gentil, D. L. (2017). A previdência social 'paga o preço' do ajuste fiscal e da expansão do poder financeiro. ABET, 16(1). https://doi.org/10.22478/ufpb.1676-4439.2017v16n1.36026

IBGE - Instituto Brasileiro de Geografia e Estatistica. (2010). Perfil dos estados, Brasil. Retrieved July 14, 2018, from http://www.ibge.gov.br/estadosat/perfil.php?sigla=ma

Marques, R. M., \& Batich, M. (1999). Os impactos da evolução recente do mercado de trabalho no financiamento da previdência. Pesquisa \& Debate, SP, 2(16), 139-154. Retrieved September 9, 2018 from http://ken.pucsp.br/rpe/article/viewFile/11918/8628

Moore, D. S. (2007). The Basic Practice of Statistics. New York, Freeman.

Peinado, J., \& Graeml, A. R. (2007). Administração da produção. Operações industriais e de serviços.

Pochmann, M. (2003). Relações de trabalho e padrões de organização sindical no Brasil. São Paulo: LTr.

Poder Executivo. (2016). Altera os arts. 37, 40, 109, 149, 167, 195, 201 e 203 da Constituição, para dispor sobre a seguridade social, estabelece regras de transição e dá outras providências. Retrieved July 18, 2018, from https://www.camara.leg.br/proposicoesWeb/fichadetramitacao?idProposicao=2119881

Queiroz, B. A. (2017). Redução do direito à proteção na maior idade: análise crítica da PEC 287/2016. Campinas Grande. Retrieved November 15, 2018, from http://dspace.bc.uepb.edu.br/jspui/handle/123456789/17184

Silva, L. L., \& Costa, T. M. T. (2016). A formação do sistema previdenciário brasileira: 90 anos de história MG. Retrieved November 25, 2018, from https://www.apgs.ufv.br/index.php/apgs/article/view/1019

Sposati, A. (1985). Assistência na trajetória das políticas sociais brasileiras. São Paulo: Cortez.

Stanton, J. M. G. (2001). Pearson and the peas: A brief history of linear regression for statistics instructors. Journal of Statistical Education, 9(3). Retrieved August 5, 2018, from http://www.amstat.org/publications/JSE/v9n3/stanton.html

Trindade, R. (2017). A evolução na demanda pela previdência privada no Brasil a partir da década de 90. Universidade Federal do Rio de Janeiro - Instituto de Economia. Retrieved February 2019 from https://pantheon.ufrj.br/bitstream/11422/4812/1/Monografia\%20Renata\%20Rangel\%20Spinola\%20Trindade.pd f

Vazquez, E. G., \& Dos Santos, V. A. L. (2010). Estudo Estatístico de Patologias na pós-Entrega de Empreendimentos Imobiliários In: Encontro Nacional de Tecnologia do Ambiente Construído. Porto Alegre: Associação Nacional de Tecnologia do Ambiente Construído. 